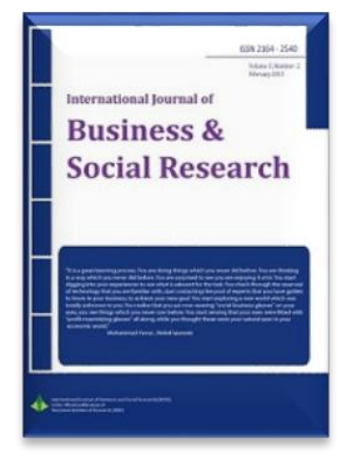

\title{
Evaluation of Vocational High Schools' Status Analysis through Student Perception: Evidence from Turkey
}

\author{
Salih Börteçine Avci', Fethullah UÇAN², Ömer Sıddık Budak ${ }^{3}$
}

\begin{abstract}
Nowadays the current status of vocational schools is handled by different sectors with a critical perspective. What will be the future status of vocational schools requires a strategic perspective. In this study, SWOT analyse was used as a method to analyse the current status of vocational schools. In order to determine the important components of SWOT (strengths, weaknesses, opportunities and threats) analyse a questionnaire prepared according to the five-point Likert scale was applied to 300 vocational school students from Ataturk University and Kafkas University in Turkey. Results being subjected to statistical analysis and were given some suggestions.
\end{abstract}

Keywords: Strategic planning, SWOT analysis, vocational schools.

Available Online: 20-03-2016

This is an open access article under Creative Commons Attribution 4.0 License, 2016.

\subsection{INTRODUCTION}

As a result of the recent increase in the requirement of qualified intermediate staff in every kind of sector in Turkey, public attention has been thrust to the vocational high schools. The fact that it is necessary for vocational high schools to experience a transformation in a way that they can fulfil the different requirements of the country has been frankly evaluated by every economic environment. The requirement of expert human resources as a part of the economic growth is a subject which has to be handled in long-term plans. Investment in human requires vision. For that reason, planning a transformation-pertinent to the present day conditions-for the universities which would fulfil the necessity of human resources will provide benefit in terms of contribution to the qualified labour in the country and regional development.

\footnotetext{
${ }^{1}$ Ataturk University, Turkey. Email: salihbortecine@gmail.com

${ }^{2}$ Ataturk University, Turkey. Email: fethullah.ucan@atauni.edu.tr

${ }^{3}$ Kafkas University, Turkey. Email: omersiddikbudak@hotmail.com
} 
Advanced countries' transition to information society raised the necessity for the universities and educational institutions to be transformed. The effort of the country to be integrated into the west and European Union (EU) full membership negotiations provided a basis for the universities to take concrete steps for the transformation process. Bologna process is the most significant example of this situation.

In accordance with these developments, Council of Higher Education, all the universities in the country formed strategic plans by taking internal and external environmental analysis as a reference. Strategic Planning Guide for Public Administrations published by the State Planning Organization in 2006 has the aim at guiding public administrations through the process of strategic planning. The following year, Higher Education Strategy Report of Turkey has been prepared by the Council of Higher Education. In accordance with that, what came into prominence is that all the universities in the country and all the faculties, vocational high schools and institutes which are in service at the level of these universities are required to prepare a strategic plan. However, when a general evaluation has been performed, it is seen that the number of the vocational high schools of the universities which have a strategic plan is below the half of the total number.

It has been determined that none of the vocational high schools has a strategic plan neither in Ataturk University which has 12 vocational high schools and nor Kafkas University which has 7 vocational high schools. However, the fact that those educational institutions, which provide supply in terms of human resources to the significant sectors for the country's economic development, do not have a strategic plan is a crucial deficiency.

Before preparing a strategic plan, evaluation of strong and weak aspects through handling environmental opportunities and threats is a de facto in literature. In this context, a Swot analysis has been carried out in the vocational high schools of Ataturk University and Kafkas University in order to simplify the handling of strong and weak aspects and environmental opportunities and threats. In this study, each factor of the Swot analysis has been subjected to rating and their level of importance has been emphasized in itself.

\subsection{SWOT ANALYSIS}

When we look at the history of the Swot analysis, we see that Heinz Weihrich who is a professor of administration in San Francisco University used the term Swot analysis in his article titled as 'Long Range Planning' (Cebecioğlu, 2006). Although the term Swot analysis has been used in the field of business management for the first time in 1970s, later on it has been commonly used in various fields in order to analyse the current situation and make planning in those areas (Demir ve Yılmaz, 2010).

Swot analysis is a process in which important factors for strategic decision taken in organizations are interpreted according to the concept of success (Demir ve Yılmaz, 2010). According to Cebecioğlu, determining the weak and strong aspects by making status evaluation of the organizations as well as determining the opportunities and threats by evaluating the environmental conditions forms the process of swot analysis.

Swot analysis is comprised of the initial letters of Strengths, Weaknesses, Opportunities and Threats and it is also known as GZFT analysis in Turkish because of the initial letters of these vocabularies in Turkish language (Acar, 2007). Swot analysis is one of the most important steps of the strategic plans. The basic target in Swot analysis is obtaining the information which is required by the businesses and organizations during planning (Uçar ve Doğru, 2005).

In order to accomplish the targets of the organization, the first thing to do is to review the appropriateness of the internal factors. The present sources, sufficiency, insufficiency and disadvantages of the organization form the internal environmental factors. During the formation of internal environmental factors, organization's history, structure of management and personnel, equipment sufficiency and sub-structure should be taken into consideration. As a result of the analysis of internal 
environmental factor, determining organization's current status, weaknesses and strengths is accomplished (Cebecioğlu, 2006).

Environmental factors which cannot be controlled by the organizations but have a direct impact upon the success of the organization form the external factors. In order for the organization to gain success, it has to touch upon the environmental threats that are influential on the surrounding opportunities or the failure of the organization.

External environmental factors should not be confused with internal factors. It is important to have an objective evaluation while determining the external environmental factors; because the future opportunities and probable threats of the organization can be life-changing (Filiz, 1996). Opportunities and threats determined for the organizations have a directive quality for the strategic plans of the organization (Dinçer, 2004).

\subsection{METHODOLOGY}

This study has been carried out with the purpose of researching on how to determine the level of importance of the factors which should be taken into consideration during a swot analysis that can foresight a strategic planning in vocational high schools. In addition, this study has been carried out in the light of expert academics' opinions and perceptual evaluations of the students as foreign customers. Interviews have been carried out for each factor in Swot Analysis. Strengths and weaknesses that can be discussed in internal evaluation of a vocational high school have been determined in the light of academics' opinions and literature review, environmental opportunities and threats expected for the vocational high schools have been discussed. Designated factors have been presented to the students in forms prepared with 5 point Likert scale, and their perceptual evaluations on the determinant subjects of each factor have been taken.

In this study, where a swot analysis has been carried out, the questionnaire which has been prepared under the guidance of expert Academics was filled out by the students of two vocational high schools. The results have been subjected to statistical analysis and the findings have been evaluated.

\subsection{GROUNDMASS AND SAMPLE}

Within the scope of this study, Ataturk University and Kafkas University, out of those vocational high schools without strategic plan, have been determined as the groundmass of this study. Two vocational high schools of Ataturk University and one from Kafkas University have been chosen as samples.

\begin{tabular}{|c|c|c|c|c|c|}
\hline \multicolumn{6}{|c|}{ Table 1: Demographic factors } \\
\hline Gender & Frequency & $\%$ & University & Frequency & $\%$ \\
\hline Male & 168 & 58.9 & Ataturk University & 186 & $65 \cdot 3$ \\
\hline Female & 117 & 41.1 & Kafkas University & 99 & 34.7 \\
\hline Total & 285 & 100 & Total & 285 & 100 \\
\hline Department & Frequency & $\%$ & Type of Education & Frequency & $\%$ \\
\hline Logistic Management & 38 & $13 \cdot 34$ & Daytime Education & 177 & 62.11 \\
\hline Business Management & 31 & 10.88 & Evening Education & 108 & 37.9 \\
\hline Bureau Management & 100 & 35.09 & Total & 285 & 100 \\
\hline Engineering & 86 & 30.18 & & & \\
\hline Tourism & 15 & 5.26 & & & \\
\hline $\begin{array}{l}\text { Private Security and } \\
\text { Protection }\end{array}$ & 11 & 3.86 & & & \\
\hline Total & 285 & 100 & & & \\
\hline
\end{tabular}

Demographic factors related to the sample have been shown in Table 1. Students from 7 departments of vocational high schools were applied that questionnaire in the study. 177 of them were students of daytime education, 108 of them were students of evening education. 


\subsection{ANALYSIS AND FINDINGS}

In this study, Swot analysis factors prepared with 5 point Likert scale (1: Absolutely Disagree, 5: Strongly Agree) have been presented to the students of vocational high schools for evaluation. Students were not forced to write their names on the questionnaire forms so that they filled the forms objectively. The results obtained have been analyzed through average and standard deviation values thanks to the SPSS20,0 program, each question have been rated taking into consideration the level of their importance.

Table 2: Students' perceptual evaluations related to the strengths

\section{Factor $=$ Strengths}

\begin{tabular}{|c|c|c|c|c|}
\hline No & Title & Average & Standard Deviation & Rating \\
\hline G11 & Having young and dynamic teaching staff & 3.80 & 1.44 & 1 \\
\hline G3 & Quality of the application of education & 3.70 & 1.37 & 2 \\
\hline G10 & Quality of theoretical education & 3.60 & 1.49 & 3 \\
\hline G2 & Convenient structure of the campus for growth & 3.60 & 1.37 & 4 \\
\hline G9 & $\begin{array}{l}\text { Being able to have flexible education in daytime and evening } \\
\text { education }\end{array}$ & $3 \cdot 50$ & 1.37 & 5 \\
\hline G8 & Vocational High Schools' addressing to all over the country & 3.48 & 1.42 & 6 \\
\hline G4 & Course books it offers and quality of systematic sources & 3.41 & 1.37 & 7 \\
\hline G7 & $\begin{array}{l}\text { Having an opportunity to prepare for the licenced state } \\
\text { examinations }\end{array}$ & 3.37 & 1.45 & 8 \\
\hline G1 & Having international standards & $3 \cdot 34$ & 1.47 & 9 \\
\hline G6 & Hosting national conferences & 3.09 & 1.45 & 10 \\
\hline G5 & Running of scientific student clubs & 3.01 & 1.40 & 11 \\
\hline \multicolumn{2}{|c|}{ General average related to the strengths } & 3.45 & & \\
\hline
\end{tabular}

In the light of students' perceptual evaluations regarding internal factors of Swot analysis, looking at the evaluations in Table 2 related to the strengths, it has been found out that the average points are above 3 , i.e. the general average related to the strengths are 3.45 and all the subjects are significant. Within the direction of the evaluations carried out, when looking at the first three ranks in the rating related to the strengths; it has been seen that vocational high school has young and dynamic teaching staff, there is applied training appropriate for the educational concept of vocational high school and the quality of theoretical education is significant.

Table 3: Students' perceptual evaluations related to the weaknesses

\section{Factor $=$ Weaknesses}

\begin{tabular}{|c|c|c|c|c|}
\hline No & Title & Average & Standard Deviation & Rating \\
\hline Z8 & Limited financial resource & 3.20 & 1.41 & 1 \\
\hline Z10 & $\begin{array}{l}\text { The fact that teaching staff cannot spare enough time for the } \\
\text { students due to high work load }\end{array}$ & 3.13 & 1.42 & 2 \\
\hline Z7 & $\begin{array}{l}\text { Weak substructure of the university (such as insufficient } \\
\text { accommodation opportunities and inconvenient living conditions) }\end{array}$ & 3.09 & 1.47 & 3 \\
\hline Z9 & Generation gap between the teaching staff and the students & 3.08 & 1.37 & 4 \\
\hline Z5 & Irrelevant courses & 3.08 & 1.46 & 5 \\
\hline $\mathrm{Z1}$ & High number of the vocational school I work at & 3.07 & 1.36 & 6 \\
\hline Z11 & Weakness of teaching staff in terms of its social status & 3.06 & 1.39 & 7 \\
\hline Z2 & $\begin{array}{l}\text { Education system based on graduating students who do not reach a } \\
\text { certain quality of standards }\end{array}$ & 3.04 & 1.31 & 8 \\
\hline Z3 & $\begin{array}{l}\text { Employment of academically insufficient teaching staff in order to } \\
\text { open new departments }\end{array}$ & 3.04 & 1.37 & 9 \\
\hline Z6 & $\begin{array}{l}\text { The fact that administrative staff does not follow innovations and } \\
\text { dependence on old methods }\end{array}$ & 3.02 & 1.30 & 10 \\
\hline Z4 & $\begin{array}{l}\text { Insufficient theoretical education required for occupational } \\
\text { application }\end{array}$ & 3.00 & 1.34 & 11 \\
\hline Z12 & Low wages of the teaching staff & 2.93 & 1.42 & 12 \\
\hline
\end{tabular}


In the light of students' perceptual evaluations regarding internal factors of Swot analysis, looking at the evaluations in Table 3 related to the weaknesses, it has been found out that the average points are above 3 , i.e. the general average related to the weaknesses are 3,06 and all the subjects are significant except the one in Z12. Within the direction of the evaluations carried out, when looking at the first three ranks in the rating related to the weaknesses it has been seen that vocational high school has limited financial sources, teaching staff cannot spare enough time for the students due to high work load and weak substructure of the university (such as insufficient accommodation opportunities and inconvenient living conditions) comes into prominence. The fact that Z12 i.e. the subject of low wages of the teaching staff has been accepted as unimportant by the students with the average point 2.93 has revealed an interesting and remarkable result.

Table 4: Students' perceptual evaluations related to the opportunities

\section{Factor = Opportunities}

No Title

F7 Employers' positive contributions to university education

F5 Developments in computer technology for higher education

F6 State's possibility of arranging budget for scientific research

F4 Convenience of the region for winter and religious tourism

F2 Numerous diversification opportunities of occupational education

F3 Society's focus on life-long education

F1 Internationalization and integration studies of Higher Education

General average related to opportunities

$\begin{array}{rrr}\text { Average } & \text { Standard Deviation } & \text { Rating } \\ 3.59 & 1.49 & 1 \\ 3.55 & 1.39 & 2 \\ 3.54 & 1.35 & 3 \\ 3.40 & 1.33 & 4 \\ 3.35 & 1.33 & 5 \\ 3.34 & 1.31 & 6 \\ 3.00 & 1.40 & 7 \\ 3.40 & & \end{array}$

In the light of students' perceptual evaluations regarding external factors of Swot analysis, looking at the evaluations in Table 4 related to the opportunities, it has been found out that the average points are above 3, i.e. the general average related to the strengths are 3,40 and all the subjects are significant. Within the direction of the evaluations carried out, when looking at the first three ranks in the rating related to the opportunities; it has been seen that employers make positive contributions to university education, developments in computer technology for higher education and state's possibility of arranging budget for scientific research come into prominence.

Table 5: Students' perceptual evaluations related to the opportunities

\section{Factor $=$ Threats}

No Title

T12 Insufficient social opportunities due to socio-cultural underdevelopment of cities

T11 Insufficient scholarship opportunities due to the lack of nongovernmental organizations

State's inability in the formation of the fields such as education, planning, tracking and occupation

T8 Perpetual changes in the curriculum of vocational high schools Non-formation of teaching staff related to the developing fields of expertise

T2 Weakness of national economy

T7 Decrease in employers' support to higher education

Non-adaptation of funds appropriated for applied education to technological developments

T3 Insufficiency of institutions which inspect and organize universities

The fact that quality assurance system in education became symbolic

Excessive number of similar vocational high schools in universities throughout the country universities in the country
Defective structure of financial regulations related to the

Average

$\begin{array}{rrr}3,42 & 1,46 & 1 \\ 3,34 & 1,45 & 2 \\ 3,31 & 1,39 & 3 \\ 3,24 & 1,38 & 4 \\ 3,24 & 1,38 & 5 \\ 3,19 & 1,33 & 6 \\ 3,18 & 1,36 & 7 \\ 3,14 & 1,38 & 8 \\ 3,13 & 1,41 & 9 \\ 3,12 & 1,36 & 10 \\ 3,09 & 1,37 & 11 \\ 3,08 & 1,38 & 12\end{array}$
Standard Deviation

1,46 Rating 
In the light of students' perceptual evaluations regarding external factors of Swot analysis, looking at the evaluations in Table 5 related to the threats, it has been found out that the average points are above 3 , i.e. the general average related to the threats are 3,21 and all the subjects are significant. Within the direction of the evaluations carried out, when looking at the first three ranks in the rating related to the opportunities; it has been seen that insufficient social opportunities due to socio-cultural underdevelopment of cities in which the vocational high school is located, insufficient scholarship opportunities due to the lack of non-governmental organizations and state's inability in the formation of the fields such as education, planning, tracking and occupation come into prominence.

\subsection{CONCLUSION}

The awareness in the preparation of strategic plan is higher in the Faculties rather than the vocational high schools. It is for sure that if universities' preparation of strategic plans regardless of the strategic plans throughout the country is not appropriate in terms of applicability, it will not be logical for the universities to start preparing strategic plans in the sub-units of the university without basing the Strategic Plan. Within the scope of a mutual vision and mission, strategic plans which have been prepared or in stage of preparation by the universities should establish a ground for sub-units' formation of their own strategic plans and encourage them to do that.

As is known, strategic plan has a multi-dimensional point of view. For that reason, before preparing a strategic plan, receiving opinions of all the ends has a significant impact upon the prevention of probable long-term malfunctions. It has been revealed thanks to this study the prominent subjects during the strategic planning process of vocational high schools, thus students have been given opportunity to evaluate the situation and results that can foresight the strategic planning has been revealed thanks to Swot analysis. Receiving contributions from all the partners while constituting strategic goals will increase the possibility of adoption of these goals by everyone.

\section{REFERENCES}

Acar, E. (2007). Yarı Resmi Bir Örgütte Stratejik Planlama Uygulaması “Aydın Ticaret Odası Örneği” (Adnan Menderes Üniversitesi Sosyal Bilimler Enstitüsü, Yüksek Lisans Tezi), Aydın.

Aktan, C. C. (2006). Stratejik Yönetim ve Stratejik Planlama. Ankara: Seçkin Yayıncılık.

Atatürk Üniversitesi 2014-2018 Stratejik Planı Erişim Tarihi:01.09.2014, URL: http://www.atauni.edu.tr/\#birim=strateji-gelistirme-daire-baskanligi

Cebecioğlu, C. (2006). SWOT Analizi ve Bir İşletme Üzerine Uygulama (Gebze Yüksek Teknoloji Enstitüsü Sosyal Bilimler Enstitüsü, Yüksek Lisans Tezi), Gebze.

Demir, C. ve Yılmaz, M. K. (2010). Stratejik Planlama Süreci ve Örgütler Açısından Önemi. Dokuz Eylül Üniversitesi iktisadi ve Idari Bilimler Fakültesi Dergisi, 25,1. 69-88.

Dinçer, Ö. (2004). Stratejik Yönetim ve işletme Politikası. İstanbul: Beta Yayınları.

Filiz, A. (1996). Iş̧letmelerde Strateji Belirlemede Yönetici ve Liderin Rolü ve Önemi (Marmara Üniversitesi Sosyal Bilimler Enstitüsü, Yüksek Lisans Tezi) İstanbul

Göl, G. (1995). Gümrük Birliği'ne Geçişte Rekabet Gücünün Belirlenmesi ve Rekabetçi Pazarlama Stratejileri (Marmara Üniversitesi Sosyal Bilimler Enstitüsü, Doktora Tezi) İstanbul

Mesleki Yeterlilik Kurumu Strateji Geliştirme Birimi Stratejik Planı. Erişim Tarihi: 01.09.2014, URL: http://www.myk.gov.tr/index.php/tr/component/content/article/380

Uçar, D. ve Doğru, A.Ö. (2005). CBS Projelerinin Stratejik Planlaması ve SWOT Analizinin Yeri, TMMOB Harita ve Kadastro Mühendisleri Odası 10.Türkiye Harita Bilimsel ve Teknik Kurultayı, 28 Mart-1 Nisan

Ülgen, H. ve Mirze, S. K. (2004). Işsletmelerde Stratejik Yönetim. İstanbul: Literatür Yayınları. 